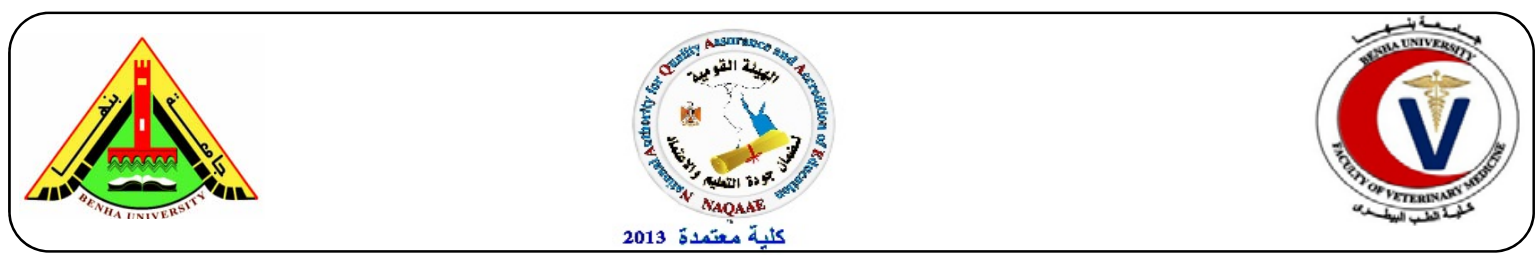

\title{
Bacteriological and Molecular studies of Listeria species in milk and milk products at El-Kaliobia Governorate
}

\author{
${ }^{1}$ Ashraf, A. Abd El Tawab, ${ }^{2}$ Ahmed, A. A. Maarouf and ${ }^{2}$ Zeinab, A.M. Mahdy \\ ${ }^{1}$ Bacteriology, Immunology and Mycology Dep., Fac. Vet. Med. Benha Univ. ${ }^{2}$ Animal Health Research \\ "Benha branch".
}

\section{A B S T R A C T}

A total of 200 random samples of raw milk, Fita cheese, Kariesh cheese and ice cream (50 samples each) were collected from small retails and different supermarkets in El-Kaliobia Governorate to estimate the prevalence of Listeria species in such products with special interest to $L$. monocytogenes. The bacteriological examination of the samples resulted; $13(6.5 \%)$ isolates of Listeria species were recovered from 200 samples, includes 10 L. monocytogenes $(5.0 \%)$ and 3 L. grayi $(1.5 \%)$. Moreover, the other 4 species (L. ivanovii; L. innocua; L. seeligeri and L. welshimeri) were not isolated from all samples (Listeria strains). The in-vitro antimicrobial sensitivity test showed that the isolated $L$. monocytogenes were sensitive to amoxicillin; gentamycin; enrofloxacin; kanamycin and ampicillin. While they were resistant to Nalidixic acid, streptomycin and tetracycline. The results of virulence tests for isolated Listeria strains appeared that all of L. monocytogenes strains were virulent strains as all of them were positive to CAMP test; showed narrow zone of $\beta$-hemolysis on sheep blood agar and were positive for Anton's test. Meanwhile, L. grayi strains were non-virulent, as none of them could produce hemolysin (CAMP test negative) and negative for Anton's test. The PCR results for L. monocytogenes showed that all genes (16S rRNA; inlA; inlB; hlyA and prfA) were detected in five studied strains $(100.0 \%)$ i.e., all studied strains were $L$. monocytogenes and all of them were virulent strains.

Keywords: Milk products, bacteriological evaluation, L. monocytogenes.

(http://www.bvmj.bu.edu.eg)

(BVMJ-29(2): 170-181, 2015)

\section{INTRODUCTION}

$\mathrm{M}$

ilk and dairy products are excellent sources of essential nutrients and casein, a major milk protein. Because of their high nutritional value, they are very suitable for development of microorganisms, including pathogenic bacteria as Listeria species (Farber and Peterkin, 1991; Kasalica et al.,2011 and El-Marnissi et al., 2013) resulting in listeriosis in both human and animals (Ryser and Marth, 2007). L. monocytogenes has been involved in many outbreaks and sporadic cases of diseases primarily associated with the consumption of pasteurized milk, cheeses made from unpasteurized milk and other dairy based products that serve as good medium for the growth and survival of many pathogenic organisms in both industrialized and developing countries (Makino et al., 2005 and Manfreda et al., 2005). The outbreaks most often occurred from consumption of raw milk and dairy products because the Listeria organism capable of slow multiplication in refrigerated foods (Fleming et al., 1985). Important characteristics of $L$. monocytogenes are its ability to grow at temperatures of $1-44^{\circ} \mathrm{C}$, at $\mathrm{pH}$ values of 5.0 and above, in high salt concentrations, and are relative resistance to freezing and drying (Lovett, 1989).

Members of the genus Listeria are short rods, aerobic to facultative anaerobic, Gram- positive, not forming spores and 
capsules, distributed individually and in form of short chains, sometimes in form of the letters $\mathrm{V}$ and $\mathrm{Y}$. In direct smear, they can be coccoid, and therefore mistaken with streptococci (Todar, 2009). Genus Listeria includes $L$. monocytogenes; $L$. ivanovii; $L$. innocua; L. seelgeri; L. welshimeri and $L$. grayi. L. monocytogenes is pathogenic for humans and animals, and L. ivanovii is mainly pathogenic for animals, primarily sheep. Other species are considered nonpathogenic. L. monocytogenes is intracellular pathogen and produces weak beta- hemolysis on blood agar. (McLaughlin, 1987; McLauchlin, 1990; Schuchat et al., 1991 and Low et al., 1993). The virulence factors of L.monocytogenes include Listeriolysin O (hlyA); internalin A (inlA); internalin B (inlB); a phosphatidylinositol- specific phosphorlipase $\mathrm{C}$ and a lecithinase, aids in intracellular invasiveness and others aid in detoxifying cytotoxic oxidants as catalase and superoxide dismutase. The genes coding for many of the virulence factors are clustered together on the chromosome and regulated by the Positive regulatory factor (prfA) gene (Mengaud et al., 1991; Portnoy et al., 1992; Renzoni , 1999 ; Gedde et al., 2000 and Michael ,2005 ). There is a link between animals and their role as a source of infection for human either as a result of occupational contact with infected animals, during lambing or calving, or after consumption of contaminated animal products as meat, milk, cheese, ice cream and yoghurt (Conly and Johnston, 2008 and El-Marnissi et al., 2013) resulting in septicemia; papular exanthema; encephalitis and abortion or stillbirth of pregnant women (Gupta et al., 2003 and Hassan et al., 2005 ). As the level of contamination of both milk and its products with Listeria species constitutes serious problems for consumers, so, the present study was conducted to estimate the prevalence of Listeria species in milk, Fita cheese, Kariesh cheese and ice cream at ElKaliobia Governorate with special interest to L.monocytogenes. In addition to clarify the virulence of isolated strains and to carry out the antibiotic sensitivity testing of them. In addition, detection of some virulence factors of L.monocytogenes by PRC technique.

\section{MATERIAL AND METHODS}

\subsection{Samples collection:}

Two hundred random samples of raw milk, Fita cheese, Kariesh cheese and ice cream (50 samples each) were collected from small retails and different supermarkets at El-Kaliobia Governorate in sterile plastic bags, kept in ice box and transferred with a minimum delay to the laboratory for studying the presence of Listeria species.

\subsection{Bacteriological examination}

A- Primary stage: One $\mathrm{ml}$ of sample was inoculated into $9 \mathrm{ml}$ Fraser broth1, half Fraser broth (without supplement) and incubated aerobically at $30 \pm 1{ }^{\circ} \mathrm{C}$ for $24 \pm 3$ hours. B- Secondary stage: One $\mathrm{ml}$ of incubated broth was inoculated into $9 \mathrm{ml}$. Fraser broth2, full strength Fraser broth (with supplement) and incubated at $37^{\circ} \mathrm{C}$ for $48 \pm 3$ hours. C- Third stage: $0.1 \mathrm{ml}$ of incubated Fraser broth was streaked onto the following media: ALOA agar; PALCAM agar and Oxford agar plates then the plates were incubated at $37 \pm 1^{\circ} \mathrm{C}$ for 48 hours and examined after $24 \pm 3$ hours. The Listeria like colonies were picked and streaked onto Tryptic Soy agar(Bio- Life) with $0.6 \%$ yeast extract(TSA,YA) then, incubated at $35^{\circ} \mathrm{C}$ for 48 hours. The isolates were morphologically identified by Gram stain and biochemical tests according to Markey et al., (2013).

\subsection{In-Vitro anti-microbial sensitivity test:}

The isolated L.monocytogenes strains were subjected to the sensitivity test against different antibiotics, using the disc and agar diffusion method (Finegold and Martin, 1982 and NCCLS, 1999).

\subsection{Virulence tests:}

A- Hemolytic activity: All isolates were cultured onto $5 \%$ sheep blood agar to 
determine their hemolytic activity. In addition to, they were subjected to CAMP (Christie-Atkins- Munoh-Peterson) test (McKellar, 1994) by streaking of Staphylococcus aureus strains in single straight lines in parallel on sheep blood agar plates, the isolated listeria strains streaked perpendicularly, with quite touching (1-2 $\mathrm{mm}$ ). After incubation for $24-48$ hours at $35^{\circ} \mathrm{C}$, a positive reaction consists of an enhanced zone of $\beta$ - hemolysis.

B- The biological characters, Anton's test (Quinn et al., 2002) by instillation 2- 3 drops of listeria suspension into the conjunctiva of rabbits.

2.5. Genotypic detection of isolated L.monocytogenes and some virulence genes in them using polymerase chain reaction (PCR)

PCR using five sets of primers was used for genotypic detection of L.monocytogenes strains and four virulence genes that may play a role in virulence of L.monocytogenes. These genes were $16 \mathrm{~S}$ rRNA gene; internalin A (inlA); internalin $\mathrm{B}$ (inlB); Listeriolysin $\mathrm{O}$, haemolysin (hlyA) and Positive regulatory factor (prfA). It was applied on five random isolated L.monocytogenes, following QIAamp ${ }^{\circledR}$ DNA Mini Kit instructions (Catalogue no. M501DP100), Emerald Amp GT PCR mastermix (Takara) with Code No. RR310A and 1. 5\% agarose gel electrophoreses (Sambrook et al., 1989). The PCR condition have specific sequence and amplify a specific product as shown in Table (3). Temperature and time conditions of the primers during PCR are shown in Table (4) according to specific authors and Emerald Amp GT PCR mastermix (Takara) kit

\section{RESULTS}

The bacteriological examination of studied samples revealed that, Listeria spp. were isolated from 11 positive samples out of 200 ones (5.5\%); represented as 3 positive samples $(1.5 \%$ and $27.3 \%)$ from raw milk;
Kariesh cheese and ice cream samples followed by $2(1.0 \%$ and $18.2 \%)$ from Fita cheese samples (Table, 1). Mixed isolates were present in raw milk samples only. Moreover, $13(6.5 \%)$ isolates of Listeria species were recovered from 200 samples, includes 10 L. monocytogenes (5.0\%) and 3 L. grayi $(1.5 \%)$. L.monocytogenes was isolated with an incidence of $76.9 \%$ ( 3 from each samples of raw milk; Kariesh cheese and ice cream $(23.1 \%)$ and $1(7.7 \%)$ from Fita cheese). Meanwhile, L. grayi was isolated with an incidence of $23.1 \%$ ( 2 from raw milk samples $(15.4 \%)$ and $1(7.7 \%)$ from Fita cheese only), percentages were calculated in relation to total number of 13 isolated Listeria species as shown in Table (2). Moreover, the other 4 species ( $L$. ivanovii; $L$. innocua; $L$. seeligeri and $L$. welshimeri) could not isolated from all samples.

The isolated colonies grow well and showed green-blue colonies surrounded by an opaque halo on ALOA agar and gray green colonies with black depressed button center and black hollow surrounded them on PALCAM agar and black colonies with dimpled centers on Oxford agar. They were Gram - positive bacilli or coccobacilli; motile showing umbrella pattern motility. Biochemical reactions showed that all strains were catalase $(+)$; oxidase $(-)$ and produce acid with dextrose, L, rhamnose but not with mannitol, D- xylose and sucrose.

The results of in vitro sensitivity test (Fig., 1) showed that, the isolated L.monocytogenes were sensitive to amoxicillin and gentamycin (80.0\%) followed by enrofloxacin; kanamycin and ampicillin (70.0\%; $70.0 \%$ and $60.0 \%$ respectively). While the isolated strains were resistant to Nalidixic acid, streptomycin and tetracycline.

The results of virulence tests proved that, all isolated L.monocytogenes strains showed narrow zone of Beta hemolysis on 5\% sheep blood agar, were CAMP test positive with zone of $\beta$ - hemolysis at the junction of tested strains and S.aureus strains. In 
addition, all of them produced purulent conjunctivitis within 24-48 hr followed by keratitis in all rabbits (Anton's test positive). Meanwhile, L. grayi strains were nonvirulent, as none of them could produce haemolysin (CAMP test negative) and negative for Anton's test.

The PCR results for $L$. monocytogenes showed that, all genes (16S rRNA; inlA; inlB; hlyA and prfA) were detected in five studied strains $(100.0 \%)$ i.e., all studied strains were L. monocytogenes and all of them were virulent strains. The $16 \mathrm{~S}$ rRNA gene was amplified in five $(100.0 \%) \mathrm{L}$. monocytogenes strains giving product of
553 bp as shown in Fig. (2). i.e., all studied strains were $L$. monocytogenes. The inlA gene was amplified in five $(100.0 \%) \mathrm{L}$. monocytogenes strains giving product of $800 \mathrm{bp}$ as shown in Fig. (3). The prfA gene was amplified in five $(100.0 \%) L$. monocytogenes strains giving product of $1052 \mathrm{bp}$ as shown in Fig. (3). The inlB gene was amplified in five $(100.0 \%) L$. monocytogenes strains giving product of $343 \mathrm{bp}$ as shown in Fig. (4). The hlyA gene was amplified in five $(100.0 \%) L$. monocytogenes strains giving product of 174 bp as shown in Fig. (4).

Table (1): Total number and Percentage of positive samples for Listeria isolation from the examined samples

\begin{tabular}{llllll}
\hline \multicolumn{1}{c}{ Samples } & Number of samples & $\begin{array}{c}\text { Number of } \\
\text { positive samples }\end{array}$ & \multicolumn{3}{c}{ Positive percentage } \\
& & & $\%^{1}$ & $\%^{2}$ & $\%^{3}$ \\
\hline Raw milk & 50 & 3 & 6.0 & 27.3 & 1.5 \\
Fita cheese & 50 & 2 & 4.0 & 18.2 & 1.0 \\
Kariesh cheese & 50 & 3 & 6.0 & 27.3 & 1.5 \\
Ice cream & 50 & 3 & 6.0 & 27.3 & 1.5 \\
$\quad$ TOTAL & 200 & 11 & 5.5 & 100.0 & 5.5
\end{tabular}

${ }^{1}$ Percentage in relation to total number of samples in each row. ${ }^{2}$ Percentage in relation to total number of positive samples (11). ${ }^{3}$ Percentage in relation to total number of collected samples (200)

Table (2): Incidence of Listeria species strains isolated from the examined samples

\begin{tabular}{l|lllllllll}
\hline Listeria species & \multicolumn{3}{l}{ L.monocytogenes } & \multicolumn{3}{l}{ L. grayi } & \multicolumn{3}{l}{ TOTAL } \\
\hline Samples & No. & $\%^{*}$ & $\%^{* *}$ & No. & $\%^{*}$ & $\%^{* *}$ & No. & $\%^{*}$ & $\%^{* *}$ \\
Raw milk & 3 & 6.0 & 23.1 & 2 & 4.0 & 15.4 & 5 & 2.5 & 38.4 \\
Fita cheese & 1 & 2.0 & 7.7 & 1 & 2.0 & 7.7 & 2 & 1.0 & 15.4 \\
Kariesh cheese & 3 & 3.0 & 23.1 & 0 & 0.0 & 0.0 & 3 & 1.5 & 23.1 \\
Ice cream & 3 & 6.0 & 23.1 & 0 & 0.0 & 0.0 & 3 & 1.5 & 23.1 \\
TOTAL & 10 & 5.0 & 76.9 & 3 & 1.5 & 23.1 & 13 & 6.5 & 100.0
\end{tabular}

* Percentage in relation to total No. of each examined sample (50 \& 200 for total). ** Percentage in relation to total No. of isolated Listeria species (13). 
Table (3): Oligonucleotide primers sequences Source

\begin{tabular}{|c|c|c|c|}
\hline Primer & Sequence & $\begin{array}{l}\text { Amplified } \\
\text { product }\end{array}$ & Reference \\
\hline $16 \mathrm{~S}$ & CCT TTG ACC ACT CTG GAG ACA GAG C & $553 \mathrm{bp}$ & Lantz et al., 1994 \\
\hline rRNA & AAG GAG GTG ATC CAA CCG CAC CTT C & & \\
\hline \multirow[t]{2}{*}{ prfA } & TCT-CCG-AGC-AAC-CTC-GGA-ACC & $1052 \mathrm{bp}$ & Dickinson et al., \\
\hline & TGG-ATT-GAC-AAA-ATG-GAA-CA & & 1995 \\
\hline \multirow[t]{2}{*}{ inlA } & ACG AGT AAC GGG ACA AAT GC & $800 \mathrm{bp}$ & Liu et al., 2007 \\
\hline & CCC GAC AGT GGT GCT AGA TT & & \\
\hline \multirow[t]{2}{*}{ inlB } & CTGGAAAGTTTGTATTTGGGAAA & $343 \mathrm{bp}$ & Kirkan et al., 2006 \\
\hline & TTTCATAATCGCCATCATCACT & & \\
\hline \multirow[t]{2}{*}{ hlyA } & GCA-TCT-GCA-TTC-AAT-AAA-GA & $174 \mathrm{bp}$ & Deneer \\
\hline & TGT-CAC-TGC-ATC-TCC-GTG-GT & & Boychuk, 1991 \\
\hline
\end{tabular}

Table (4): Cycling conditions of the different primers during cPCR

\begin{tabular}{|c|c|c|c|c|c|c|}
\hline Gene & $\begin{array}{l}\text { Primary } \\
\text { denaturation }\end{array}$ & $\begin{array}{l}\text { Secondary } \\
\text { denaturation }\end{array}$ & Annealing & Extension & $\begin{array}{l}\text { No. of } \\
\text { cycles }\end{array}$ & $\begin{array}{l}\text { Final } \\
\text { extension }\end{array}$ \\
\hline $16 \mathrm{~S}$ & $94^{\circ} \mathrm{C}$ & $94^{\circ} \mathrm{C}$ & $60^{\circ} \mathrm{C}$ & $72^{\circ} \mathrm{C}$ & 35 & $72^{\circ} \mathrm{C}$ \\
\hline rRNA & $5 \mathrm{~min}$. & $30 \mathrm{sec}$. & $45 \mathrm{sec}$ & $45 \mathrm{sec}$ & & $10 \mathrm{~min}$. \\
\hline \multirow[t]{2}{*}{ prfA } & $94^{\circ} \mathrm{C}$ & $94^{\circ} \mathrm{C}$ & $50^{\circ} \mathrm{C}$ & $72^{\circ} \mathrm{C}$ & 35 & $72^{\circ} \mathrm{C}$ \\
\hline & $5 \mathrm{~min}$. & $30 \mathrm{sec}$. & $1 \mathrm{~min}$. & $1 \mathrm{~min}$. & & $12 \mathrm{~min}$. \\
\hline \multirow[t]{2}{*}{ inlA } & $94^{\circ} \mathrm{C}$ & $94^{\circ} \mathrm{C}$ & $55^{\circ} \mathrm{C}$ & $72^{\circ} \mathrm{C}$ & 35 & $72^{\circ} \mathrm{C}$ \\
\hline & $5 \mathrm{~min}$. & $30 \mathrm{sec}$. & $45 \mathrm{sec}$. & $45 \mathrm{sec}$. & & $10 \mathrm{~min}$. \\
\hline \multirow[t]{2}{*}{ inlB } & $94^{\circ} \mathrm{C}$ & $94^{\circ} \mathrm{C}$ & $55^{\circ} \mathrm{C}$ & $72^{\circ} \mathrm{C}$ & 35 & $72^{\circ} \mathrm{C}$ \\
\hline & $5 \mathrm{~min}$. & $30 \mathrm{sec}$. & $45 \mathrm{sec}$. & $45 \mathrm{sec}$. & & $10 \mathrm{~min}$. \\
\hline \multirow[t]{2}{*}{ hlyA } & $94^{\circ} \mathrm{C}$ & $94^{\circ} \mathrm{C}$ & $50^{\circ} \mathrm{C}$ & $72^{\circ} \mathrm{C}$ & 35 & $72^{\circ} \mathrm{C}$ \\
\hline & $5 \mathrm{~min}$. & $30 \mathrm{sec}$. & $30 \mathrm{sec}$. & $30 \mathrm{sec}$. & & $7 \mathrm{~min}$. \\
\hline
\end{tabular}

\section{DISCUSSION}

Listeria species in milk and dairy products are very important for human health. $L$. monocytogenes has been involved in several outbreaks and sporadic cases of listeriosis associated with the consumption of pasteurized milk and other dairy products (Van Kassel et al., 2004 and Makino et al., 2005). Therefore, this study was conducted to estimate the prevalence of Listeria species in milk, Fita cheese, Kariesh cheese and ice cream at El-Kaliobia Governorate with special interest to L. monocytogenes and bacteriological characterization of 


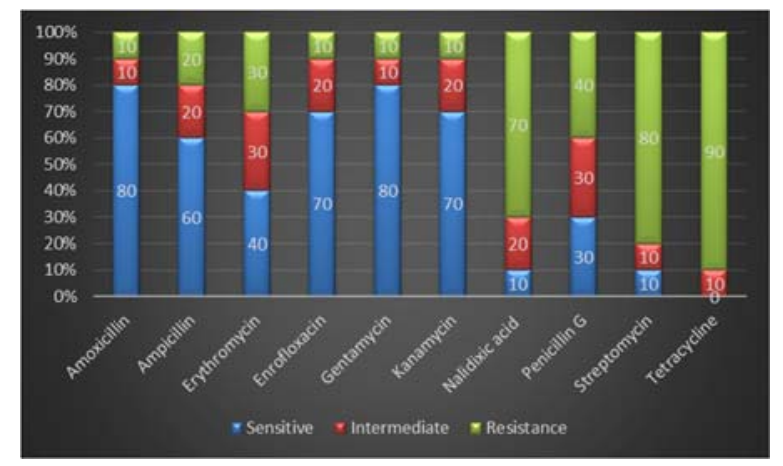

Fig. (1): In-Vitro anti-microbial Sensitivity test for isolated L.monocytogenes strains

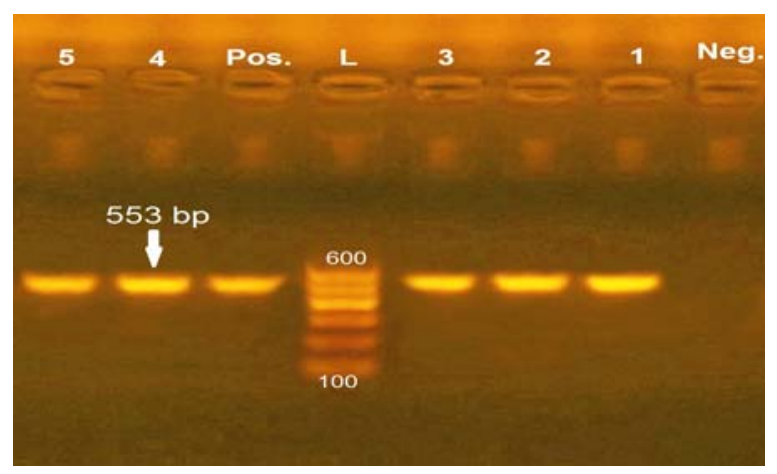

Fig. (2): 16S rRNA genes. Lane L: 100 - 600 bp Ladder. Neg.: Negative control. Pos.: Positive control (at 553 bp). Lanes 1 to 5: L. monocytogenes (16S rRNA) gene positive

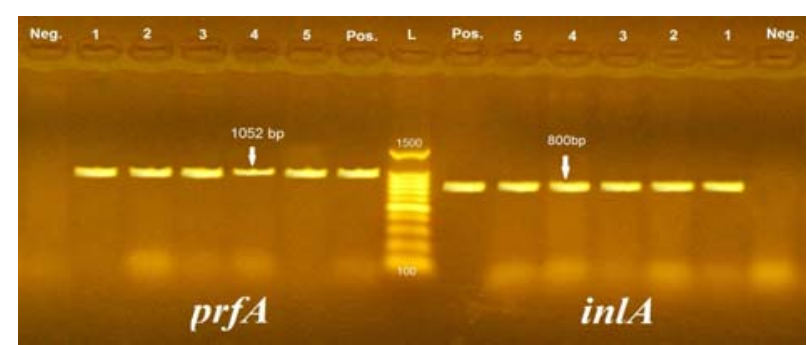

Fig. (3): internalin A (inlA) genes. Lane L: 100 - 1500 bp Ladder. Neg.: Negative control.Pos.: Positive control (at 800 bp). Lanes from right side 1 to 5: L.monocytogenes ((inlA) gene positive. Lane L: 100 - 1500 bp Ladder. Neg.: Negative control. Pos.: Positive control (at 1052 bp). Lanes from left side 1 to 5: L.monocytogenes ((prfA) gene positive.

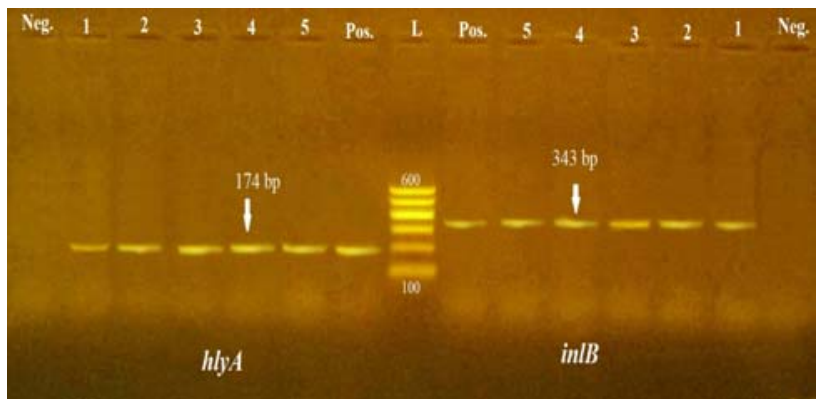

Fig. (4): internalin B (inlB) genes. Lane L: 100 - 600 bp Ladder. Neg.: Negative control. Pos.: Positive control (at $343 \mathrm{bp}$ ). Lanes from right side 1 to 5: L. monocytogenes (inlB) gene positive Lane L: 100 - 600 bp Ladder. Neg.: Negative control. Pos.: Positive control (at 174 bp). Lanes from left side 1 to 5: L. monocytogenes ((hlyA) gene positive 
them. The results of Listeria spp. isolation (Table 1) revealed that, 11 out of 200 samples were positive for isolation $(5.5 \%)$; represented as 3 positive samples $(1.5 \%$ and $27.3 \%$ ) from each type of samples of raw milk, Kariesh cheese and ice cream samples followed by $2(1.0 \%$ and $18.2 \%)$ from Fita cheese samples. Mixed isolates were present in raw milk samples only. These results came in accordance with that obtained by (EL-Malt and Abd El Hameed, 2009 and El- Marnissi et al., 2013).

The results of bacteriological examination of examined samples revealed that, a total of $13(6.5 \%)$ isolates of Listeria species were recovered from 200 samples, includes 10 L.monocytogenes $(5.0 \%)$ and 3 L. grayi (1.5\%). L.monocytogenes was isolated with an incidence of $76.9 \%$ (3 from each samples of raw milk; Kariesh cheese and ice cream $(23.1 \%)$ and $1(7.7 \%)$ from Fita cheese). Meanwhile, L. grayi was isolated with an incidence of $23.1 \%$ (2 from raw milk samples $(15.4 \%)$ and $1(7.7 \%)$ from Fita cheese only), percentages were calculated in relation to total number of 13 isolated Listeria species as shown in Table (2). Nearly similar results were recorded by Abd El -Aal and Atta, 2009; El- Marnissi et al., (2013) and Ning et al., (2013). Meanwhile, these results disagreed with those recorded by Massa et al. (1990); Morales et al. (1995) and Pednekar et al. (1997) who failed to isolate $L$. monocytogenes. Moreover, the other 4 species (L.ivanovii; L. innocua ; L. seeligeri and $L$. welshimeri ) were not isolated from all samples. These results finding go hand in hand with the finding of Farber et al. (1988) and Lund et al. (1991). Meanwhile, they disagreed with the finding of Silva et al. (1998); EL-Malt and Abd El -Hameed, 2009) who isolated them from milk and dairy product samples.

The results of antibiotic sensitivity tests for the isolated L.monocytogenes (Fig., 1) showed that, the isolated L.monocytogenes were sensitive to amoxicillin and gentamycin $(80.0 \%)$ followed by enrofloxacin; kanamycin and ampicillin $(70.0 \% ; \quad 70.0 \%$ and $\quad 60.0 \%$ respectively). While the isolated strains were resistant to Nalidixic acid, streptomycin and tetracycline. Nearly similar results were recorded by Hof et al. (1997); Al- Sadie et al. (1998); Drevets et al. (2004); Maarouf et al. (2007); Ennaji et al., (2008) and Garedew et al., (2015).

The pathogenicity of Listeria spp. is closely associated with their haemolytic activities (Cossart et al., 1989; Gedde et al, 2000 and Maarouf et al., 2007). The results of virulence tests for isolated Listeria appeared that, all L. monocytogenes were positive to CAMP test and showed narrow zone of $\beta$-haemolysis on sheep blood agar. The same results were recorded by Cossart et al. (1989); Portnoy et al. (1992) and McKellar (1994) who cited that all virulent L. monocytogenes produce a haemolysin (Listeriolysin O) which lyses the host vacuole, allowing it to grow in the host cytoplasm. For CAMP test, McKellar (1994) suggested that $S$. aureus sphingomyelinase sensitized the RBC membrane prior to complete lyses with $L$. monocytogenes. Also, all isolated strains were positive for Anton's test. This was in agreement with Sneath et al. (1986); Shafie and Amer (2002) and Maarouf et al. (2007). Therefore, all the isolated L.monocytogenes strains were virulent strains as all of them produced haemolysin (CAMP test); as well as Anton's test and catalase test were positive. Similar results were reported by Conner et al. (1989); McKellar (1994); Vazquez - Boland et al (2001) and Maarouf et al. (2007). Meanwhile, L. grayi strains were non-virulent, as none of them could produce haemolysin (CAMP test negative) and negative for Anton's test.

The PCR results for L.monocytogenes showed that, all genes (16S rRNA; inlA ;inlB; hlyA and prfA) were detected in five studied strains $(100.0 \%)$ i.e., all studied strains were L.monocytogenes and all of them were virulent strains. Similar results were decided by ( Dramsi et al., 1996; Kuhn and Goebel ,1999; Jaradat et al., 2002; 
Joseph and Goebel, 2007; Gelbicova and Karpiskova (2012); Shen et al., 2013 and Ciolacu et al., (2015). Regarding to the occurrence of $16 \mathrm{~S}$ rRNA genes in L.monocytogenes isolates. The obtained result revealed that, it was amplified in all tested five $(100.0 \%)$ L.monocytogenes strains giving product of $553 \mathrm{bp}$ as shown in Fig. (2). i.e., all studied strains were L.monocytogenes. These results came in accordance with those recorded by Holko et al., (2002); Michael et al., (2005); Schuerch et al., (2005); Liu et al., (2007); Gelbicova and Karpiskova (2012); Swetha et al., 2012 and Ciolacu et al., (2015). They reported that, PCR save time for diagnosis hence allowing a rapid identification of L.monocytogenes with high sensitivity and specificity. The results of PCR for amplification of internalin A (inlA) gene in L.monocytogenes (Fig., 3) showed that, the inlA gene was amplified in five $(100.0 \%)$ strains giving product of $800 \mathrm{bp}$. Similar findings were recorded by Almeida and Almeida (2000); Jaradat et al., (2002); Joseph and Goebel (2007); Liu et al., (2007); Gelbicova and Karpiskova (2012) Shen et al., (2013) and Ciolacu et al., (2015). The results of PCR for amplification of Positive regulatory factor (prfA) gene in L.monocytogenes (Fig., 3) showed that, the prfA gene was amplified in five $(100.0 \%)$ strains giving product of $1052 \mathrm{bp}$. Similar findings were recorded by Holko et al., (2002); Jaradat et al., (2002); Begley et al., (2005); Liu et al., (2007); Joseph and Goebel ,(2007); Seveau et al., (2007); Lemon et al., (2010); Gelbicova and Karpiskova (2012); Shen et al., 2013 and Ciolacu et al., (2015) who reported that, this gene positively regulates all virulence factors in L. monocytogenes. The results of PCR for amplification of internalin B (inlB) gene in L.monocytogenes (Fig., 4) showed that, the inlB gene was amplified in five $(100.0 \%)$ strains giving product of $343 \mathrm{bp}$. Similar findings were recorded by Jaradat et al., (2002) Dongyou Liu (2006); Kirkan et al., (2006); Joseph and Goebel (2007) and Gelbicova and Karpiskova (2012). The results of PCR for amplification of Listeriolysin $\mathrm{O}$, haemolysin (hlyA) gene in L. monocytogenes (Fig., 4) showed that, the hlyA gene was amplified in five $(100.0 \%)$ strains giving product of $174 \mathrm{bp}$. Similar findings were recorded by Jaradat et al., (2002); Schuerch et al., (2005); Joseph and Goebel, (2007); Rawool et al., (2007); Gelbicova and Karpiskova (2012); Swetha et al., (2012); Khan et al., (2014); Mohamed, (2014) and Ciolacu et al., (2015).

Finally, from results of the present work it could be concluded that, Listeria species specially, L.monocytogenes are important pathogens could be contaminate the milk and milk products as Fita cheese and ice cream and causes a foodborne disease( listeriosis). The isolated L.monocytogenes were sensitive to amoxicillin; gentamycin; enrofloxacin; kanamycin and ampicillin and were resistant to Nalidixic acid, streptomycin and tetracycline. PCR results were in complete agreement with those obtained from standard cultural procedures, as, all 5 studied strains were $L$. monocytogenes and all of them had virulent genes with $100 \%$, moreover, all the isolated L. monocytogenes strains produced B zone of hemolysis and CAMP test positive; as well as Anton's test and catalase test were positive.

\section{REFERENCES}

Abd El Aal, S.F.A., Atta, M.A.H.B. 2009. Occurrence of Listeria and Yersinia species in milk and some milk products. Assuit Vet. Med. J. 55(123):45-60.

Almeida, P.F., Almeida, R.C. 2000. A PCR protocol using inL gene as a target for specific detection of $L$. monocytogenes. J. Food Control, 11:97-101.

Al-Sadie, H.L., Sawa, M.I., AI-Attar, M.Y., Yousif, Y.A. 1998. The survival time, pathogenicity and in vitro sensitive to local ovine and caprine 
isolates of L. monocytogenes. Iraqi J.Vet. sci., 1127(2):71-78.

Begley, M., Sleator, R.D., Gahan, C.G., Hill, C. 2005. contribution of three bile- associated loci, bsh, pva and btlB to gastrointestinal persistence and bile tolerance of Listeria monocytogenes. Infect. Immun 73:894-904.

Ciolacu, L., Nicolau, A.I., Wagner, M., Rychli, $\quad$ K. 2015. Listeria monocytogenes isolated from food samples from a Romanian black market show distinct virulence profiles. Int. J. Food Microbiol., 209 :44-51.

Conly, M.J., Johnston, M.D. 2008. Listeria: A persistent food-borne pathogen. Can. J. Infect. Dis. Med. Microbiol., 19: 327-328.

Conner, D.E., Scott, V.N., Sumner, S.S., Bernard, D.T. 1989. Pathogenicity of food borne, environmental and clinical isolates of Listeria monocytogenes in mice. J. Food Sci., 54: 1553-1556.

Cossart, P., Vicente, M.F., Mengaud, J., Baquero, F., Perez-Diaz, J.C., Berche, P. 1989. Listeriolysin $\mathrm{O}$ is essential for virulence of Listeria monocytogenes: Direct evidence obtained by gene complementation. Infect. Immun., 57: 3629-3636.

Deneer, H.G., Boychuk, I. 1991. SpeciesSpecific Detection of Listeria monocytogenes by DNA Amplification. Applied and environmental microbiology, pp: 606-609.

Dongyou, Liu. 2006. Identification, subtyping and virulence determination of Listeria monocytogenes, an important foodborne pathogen. J. of Medical Microbiology (55): 645-659.

Dickinson, J.H., Kroll, R.G., Grant, K.A. 1995. The direct application of the polymerase chain reaction to DNA extracted from foods. Letters in Applied Microbiology, 20: 212-216.

Dramsi, S., Lebrun, M., Cossart, P. 1996. Molecular and genetic determinants involved in invasion of mammalian cells by Listeria monocytogenes, Curr. Top. Microbiol. Immunol. ,209 : 61-77.

Drevets, D.A., Leenen, P.J.M., Greenfield, R.A. 2004. Invasion of the central nervous system by intracellular bacteria. Cline. Microbiol. Rev., 17 (2): 323-347.

El-malt, Laila, M., Abdel hameed, Karima, G. 2009. Occurrence of listeria species in raw cow's milk \& ice cream sold in qena city. Assiut Vet. Med. J. 55(121):180-191.

El-Marnissi, B., Bennani, L., Cohen, N., Lalami, A.E., Belkhou, R. 2013. Presence of Listeria monocytogenes in raw milk and traditional dairy products marketed in the north central region of Morocco.African J.Food Science, 7(5):87-91.

Ennaji, H., Timinouni, M., Ennaji, M., Hassar, M., Cohen, N. 2008. Characterization and antibiotic susceptibility of L.monocytogenes isolated from poultry and red meat in Morocco. Infection and Drug Resistance 1:45-50.

Farber, J.M., Peterkin, P.I. 1991. Listeria monocytogenes a food-borne pathogen. Microbiol. Rev., 55: 476511.

Farber, J.M., Sanders, G.W., Malcom, S.A. 1988. Detection of Listeria species in raw milk in Ontario. Can J. Microbiol., 34: 95-100.

Finegold, S.M., Martin, W.J. 1982. Bailley and Scott Diagnostic Microbiology 6th ed., C.V. Mosby Co. St. Louis. Toronto, London.

Fleming, D.W., Cochi, S.L., MacDonald, K.L., Brondum, J., Hayes, P.S., Plikaytis, B.D., Holmes, M.B., Audurier, A., Broome, C.V., Reingold, A.L. 1985. Pasteurized milk as vehicle of infection in 
outbreak of Listeriosis. New Engl. J. Med., 312: 404-407.

Garedew, L., Taddese, A., Biru, T., Nigatu, S., Kebede, E., Ejo, M., Fikru, A., Birhanu, T. 2015. Prevalence and antimicrobial susceptibility profile of listeria species from ready-to-eat foods of animal origin in Gondar Town, Ethiopia BMC Microbiology, 15:100.

Gedde, M.M., Higgins, D.E., Tilney, L.G., Portnoy, D.A. 2000. Role of Listeriolysin $\mathrm{O}$ in cell to cell spread of Listeria monocytogenes. Infect. Immun., 68: 999-1003.

Gelbicova,T. , Karpiskova, R. 2012. Outdoor environment as a source of L.monocytogenes in Food Chain Czech J. Food Sci. 30(1): 83-88.

Gupta, V., Gautam, V., Mehta, N. 2003. Listeriosis in second trimester of pregnancy: Case report from India. Tpn.J. Infect. Dis., 56: 60-61.

Hassan, M.A., Mohamed, M.A., Nashwa, O. Khalifa.2005. Zoonotic aspects of L. monocytogenes in Pregnant and post-partum women. Benha Vet. Med. J., 16 (2): 43-53.

Hof, H., Nichterlein, T., Kretschmar, M. 1997. Management of Listeriosis. Clin. Microbiol. Rev., 10:345-357.

Holko, I., Urbanova, J., Kantikova, M., Pastorova, K., Kmee, V. 2002. PCR Detection of Listeria monocytogenes in Milk and Milk Products and Differentiation of Suspect Isolates. ACTA VET. BRNO (71): 125-131.

Jaradat, Z.W., Schutze, G.E., Bhunia, A.K. 2002. Genetic homogeneity among L.monocytogenes strains from infected patients and meat products from two geographic locations determined by phenotyping, ribotyping and PCR analysis of virulence genes. Int. J. of Food Microbiology, 76:1-10.

Joseph, B., Goebel, W. 2007. Life of Listeria monocytogenes in the host cells cytosol. Microbes Infect (9): 1188-1195.
Kasalica, A., Vukovic,V., Vranjes, A., Memisi, N. 2011. Listeria monocytogenes in milk and dairy products. Biotechnology in Animal Husbandry, 27(3):1067-1082.

Khan, J.A., Rathore, R.S., Khan, S., Ahmad, I. 2014. In vitro detection of pathogenic Listeria monocytogenes from food sources by conventional, molecular and cell culture method. Braz. J. Microbiol., 44(3):751-759.

Kirkan, S., Goksoy, E.O., Kaya, O. 2006. Detection of Listeria monocytogenes by using PCR in Helix pomatia. Turk. J. Vet. Anim. Sci.30:375-380.

Kuhn, M., Goebel, W. 1999. Pathogenesis of Listeria monocytogenes, p. 97130. In Ryser ET and Marth EH (eds.), Listeria, Listeriosis, and Food Safety. New York.

Lantz, P.G., Hahn-Hagerdal, B., Rådström, P. 1994. Sample preparation methods in PCR-based detection of food pathogens. Trends Food Sci. Technol. 5:384-389.

Lemon, K.P., Freitag, N.E., Kolter, R. 2010. The virulence regulator prfA promotes biofilms formation by Listeria monocytogenes. J. Bacteriol. 192(15):3969-3976.

Liu, D., Lawrence, M.L., Austin, F.W., Ainsworth, A.J. 2007. A multiplex PCR for species and virulence specific determination of $L$. monocytogenes. J. Microbiol. Methods (71): 133-140.

Lovett, J. 1989. Listeria monocytogenes. In M.P. Doyle (Ed.), Foodbome Bacterial Pathogens (pp. 283-310). New York: Marcel Dckker.

Low, J.C., Wright, F., McLauchlin, J., Donnachie, W. 1993. Serotyping and distribution of Listeria isolates from cases of ovine listeriosis. Vet. Rec., 133:165-166.

Lund, A.M., Zottola, E.A., Pasch, D.J. 1991. Comparison of methods for isolation of Listeria from raw milk. J. Food Prot, 54:602-606. 
Maarouf, A.A., El-Bealawy, M.A., Moubarak, M.G. 2007. Some studies of Listeriosis in sheep at El-Kaliobia governate. J. Egypt. Vet.Med.Assoc. 67(4):27-40.

Makino, S.I., Kawamoto, K., Takeshi, K., Okada, Y., Yamasaki, M., Yamamoto, S. 2005. An outbreak of food-borne Listeriosis due to cheese in Japan, during 2001. Int. J. Food Microbiol. 104: 189-96.

Manfreda, G., De Cesare, A., Stella, S., Cozzi, M., Cantoni, C. 2005. Occurrence and ribotypes of Listeria monocytogenes in Gorgonzolia cheese. Int. J. Food Microbiol.. 102: 287-93.

Markey, B.K., Leonard, F.C., Archambault, M., Cullinane, A., Maguire, D. 2013. Clinical Veterinary Microbiology. Second edition. MOSBY. Elsevier Ltd. Edinburgh London New York Oxford Philadelphia St Louis Sydney Toronto.

Massa, S., Cesaroni, D., Poda, G., Trovattelli, L.D. 1990. The incidence of Listeria species in soft cheeses, butter and raw milk in the province of Bologna. J. Appl. Bact., 68(2): 153-156.

McKellar, R.C. 1994. Use of the CAMP test for identification of Listeria monocytogenes. Appl. Environ. Microbiol., 60 (12): 4219-4225.

McLauchlin, J. 1990. Distribution of serovars of Listeria monocytogenes isolated from different categories of patients with listeriosis. Eur. J. Clin. Microbiol. Infect. Dis. 9:210-213.

McLaughlin, J. $1987 . \quad$ Listeria monocytogenes, recent advances in the taxonomy and epidemiology of Listeriosis in humans. J. Appl. Bacteriol., 63: 1-11.

Mengaud, J., Braunbreton, C., Cossart, P. 1991. Identification of phosphatidylinositol - specific phospholipase $\mathrm{C}$ activity in Listeria monocytogenes a novel type of virulence factor. Mol. Microbiol., 5: 367-372.

Michael, W.S., Ngc, E.Y.W., Robert, L., Melanie, E., Marion Walchera, M., Kreftc, J., Werner, G., Michael, W., Karl-Heinz Schleifera, K. 2005. Evolutionary history of the genus Listeria and its virulence genes. Systematic and Applied Microbiology, (28): 1-18.

Mohamed, Rasha, A. 2014. Molecular characterization of Listeria monocytogenes isolated from milk.B.V.SC. Suaz canal unv.

Morales, A.L., De La, A.O., Sandoval, V., Barbosa, R. 1995. Prevalence of L. monocytogenes in raw milk in Guadalajara, Mexico. J. Food Prot., 58 (10): 1139-1141.

NCCLS .1999. National Committee for Clinical Laboratory Standarts. Performance Standards for Antimicrobial Disk and Dilution Susceptibility Tests for Bacteria Isolated from Animals. Approved Standard M31-A. NCCLS, Wayne, USA.

Ning, N., Guo, K., Cheng, L., Xu, L., Zhang, C., Cui, H., Cheng, Y., Xu, R., Liu W., Lv, Q., Cao, W. , Zhang, Y. 2013. Pilot survey of raw whole milk in China for Listeria monocytogenes using PCR. Food Control., 31: 176-179.

Pednekar, M.D., Kamat, A.S., Adhikari, H.R. 1997. Incidence of Listeria species in milk and milk products. Ind. J. Dairy Sci., 50 (2): 142-151.

Portnoy, D.A., Chakraborty, T., Goebel, W., Cossart, P. 1992. Molecular determinants of Listeria monocytogenes pathogenesis. Infect. Immun., 60: 1263-1267.

Quinn, P.J., Markey, B.K., Carter, M.E., Donnelly, W.J.C., Leonard, F.C. Maguire, D. 2002.Veterinary microbiology and microbial disease. 
Iowa State Univ Press, Blackwell Science Ltd, 84-96.

Rawool, D.B., Malik, S.V., Shakuntala, I., Sahare, A.M., Barbuddhe, S.B. 2007. Detection of multiple virulenceassociated genes in L. monocytogenes isolated from bovine mastitis cases. Int. J. Food Microbiol 113(2): 201-207.

Renzoni, A., Cossart, P., Dramsi, S. 1999. PrfA, the transcriptional activator of virulence genes, is upregulated during interaction of Listeria monocytogenes with mammalian cells and in eukaryotic cell extracts. Mol. Microbiol. (34):552-561.

Ryser, E.T., Marrth, E. 2007. Listeria,Listeriosis and Food Safety. $3^{\text {rd. }}$ Ed. Taylor and Francis. Boca Raton,Fl.

Sambrook, J., Fritscgh, E.F., Mentiates. 1989. Molecular coloning. A laboratory manual. Cold spring Harbor Laboratotry press, New York.

Schuchat, A., Swaminathan, B., Broome, C.V. 1991.Epidemiology of human Listeriosis. Clin. Microbiol. Rev., 4:169-183.

Schuerch, D.W., Wilson-Kubalek, E.M., Tweten, R.K. 2005. Molecular basis of listeriolysin $\mathrm{O} p H$ dependence. Proc. Natl. Acad. Sci. U.S.A. 102(35): 12537-12542.

Seveau, S., Pizarro-Cerda, J., Cossart, P. 2007. Molecular mechanisms exploited by Listeria monocytogenes during host cell invasion. Microbes Infect 9: 1167-1175.

Shafie, S.A. Soumaya , Amer, H.A. 2002. An attempt to control the major manifestations (abortion and nervous symptoms) attributed to Listeria monocytogenes infection in sheep. Vet. Med. J. Giza., 50 (4): 639 - 656.

Shen, J., Rump, L., Zhang, Y., Chen, Y., Wang, X., Meng, J. 2013. Molecular subtyping and virulence gene analysis of L.monocytogenes isolates from food. Food Microbiology (35): 58- 64.

Silva, M.C.D., Vilardi, T.C.C., Tibana, A. 1998. Evalution of methods for detection of Listeria from Brazilian cheese. Ciencia e Technologia de Alimentos, 18 (2): 150-155. Dairy Sci. Abst., (1999): 61(5): 326.

Sneath, P.H.A., Mair, N.S., Shorpe, M.E., Holt, J.G. 1986. Bergey's Manual of systemic Bacteriology., Williams and Wilkins, Baltimore, Hon Kong. London.

Swetha, C.S., Madhava Rao, T., Krishnaiah, N., Vijaya Kumar, A. 2012. Detection of L.monocytogenes in fish samples by PCR assay. Annals of Biological Research, 3 (4): 18801884.

Todar, K. 2009. "Listeria monocytogenes". Todar/s Online Textbook of Bacteriology., htt:// textbookof bacteriology.net/Listeria.html.

Van Kessel, J.S., Karn, S., Gorsici, L. 2004. Prevalence of Salmonellae, Listeria monocytogens and fecal coliforms in bulk tank milk on US dairies. J. Dairy Sci., 87: 2822-2830.

Vazquez- Boland, J.A., Kuhn, M., Berche, P., Chakraborty, T., Dominguez Bernal, G., Goebel, W., GonzalezZorn, B., Wehland, J., Kreft, J. 2001. Listeria pathogenesis and molecular virulence determinants. Clin. Microbial. Rev., 14 (3): 584-640. 